\title{
THE PEASANT POOR AND IMAGES OF POVERTY: FINNISH PROVERBS AS DISCURSIVE REPRESENTATIONS OF CULTURAL KNOWLEDGE
}

\author{
Eija Stark
}

\begin{abstract}
This article examines the core idea of poverty proverbs as hints of cultural knowledge in old Finnish rural countryside. Until World War II, most of the Finns lived in a high-risk society with only few institutions to guarantee their safety and well-being. The continuous threat of absolute poverty was evident for the majority of the Finns. The basis of this research is 204 proverbs that contain the words poor, poverty, pity or unfortunate. The proverbs analyzed and classified here were collected in the Folklore Archives of the Finnish Literature Society between the years 1885 and 1950. The ideational level of the proverbs in the context of social history is crucial in revealing the schematic structure that people use to communicate about rural poverty.
\end{abstract}

Keywords: cultural knowledge, Finland, folk ideas, peasant poverty, proverbs

Throughout the nineteenth and well into the twentieth century, the majority of the population in Finland remained agrarian and poor. By World War II, more than half of the Finns still lived in rural areas and most of them earned their living primarily from agriculture and forestry. Urbanization proceeded rapidly from the 1960s onwards. This paper focuses on the idea of the cultural knowledge and shared understanding that ordinary people, 'folk', had of the concepts and ideas concerning the rural-based poverty in Finland at the end of the 19 th and the beginning of the 20 th centuries. The basis of this article is a corpus of 204 Finnish proverbs that contain the words poor, poverty, pity or unfortunate; of these, 54 have been selected as examples of a certain theme of cultural knowledge. ${ }^{1}$ Some of the proverbs were explained by the informants. Therefore, I also carefully scrutinized every explanation provided by the informants for any given proverb text, if such was available. The article does not explore what is distinctive about Finnish proverbs but rather, how semiliterate poor peasants, the majority of the Finns in the relatively recent past, described their universe of experience from the point of view of living standards. The 
perspective is on what folklorist Alan Dundes would have called "folk ideas" about the "traditional notions that people in common culture have about the nature of man, of the world and of man's life in the world" (Dundes 1972: 95). Just as Dundes argues, proverbs are useful in trying to understand folk thought and cultural knowledge.

By defining the concept of folk ideas, Alan Dundes did not discuss the role of social or historical context of a proverb, but instead, stated that folk ideas are expressed in a great variety of different genres and they might also appear in non-folklore materials (Dundes 1972: 95). The premise of this analysis is that people of equal socio-economic status share their understandings of the world that they have learned and internalized in the course of their similar experiences. Individuals rely on these shared understandings to comprehend actions and to evaluate other people's actions. Even though the sample proverbs selected for the present article are analyzed in relation to northern European and Finnish social history, many of the proverbs are internationally known, for example, in Africa (Kimilike 2006). Indeed, many of them can be dated back far into history but can also be familiar to contemporaries. I assume that many cultural ideas of the poverty proverbs are rooted more in the experience of absolute poverty than in a geographically separate culture, such as northern European or Finnish. Regardless of this, proverbs cannot be understood without reference to a vast knowledge of the early rural 20th century Finnish context. One of the most significant aspects is that in the past proverbs in Finland were a form of speech used by individuals that constituted the minority from the point of view of social power (Granbom-Herranen 2010: 94). The proverbs analyzed in this article have been collected from the Finnish-Karelian rural communities.

Life in this rural culture was uncertain and risky. At the turn of the century, less than 40 percent of all households in the countryside were landowning families. Moreover, more than half of the Finnish landowners were smallholders, cultivating less than ten hectares of arable land (Peltonen 1995: 33). The other two peasant household groups were tenant farmers, constituting 20 percent of the rural population, and farm labourers, making up 40 percent of all the households (Alanen 1995: 44-45). Since agriculture in a harsh climate and on a small piece of land did not provide self-sufficiency, sources of livelihood were many and therefore, various types of small leaseholders and agricultural workers formed the majority of the rural population. For example, logging was a vital source of income for both the landless population and for those owning a small farm in the rural area. 


\section{THE PROVERB SAMPLE}

The proverbs discussed here originate from the Folklore Archives of the Finnish Literature Society and were collected between 1885 and 1950. The people behind the proverbs represented mainly the rural working-class and peasants. These groups formed the majority of the population in that period and were considered as the active folklore users. The most common method of collecting for an interviewer was to ask a member of the 'folk' to recall all types of proverbs or proverbial sayings. These interviewers were often young, Finnish and Swedish-speaking undergraduates with nationalistic enthusiasm, ${ }^{2}$ but also other members of the peasantry. In Finland, many representatives of the 'folk' contributed large collections of all types of folklore texts, jotting down notes concerning oral tradition over the years or collecting material from their home parish, and subsequently sending them to the Folklore Archives. ${ }^{3}$ This method of collecting was encouraged by the Folklore Archives, which donated paper and instruction manuals to assist these folk collectors (Stark-Arola 1998: 54).

Later on, folklore questionnaires were organized by the Folklore Archives of the Finnish Literature Society and were announced to the public in the media, mainly in newspapers and magazines. Among the most comprehensive ones was a questionnaire of the Kalevala jubilee in 1935-36, in which ordinary people were encouraged to send in all types of folklore to the Folklore Archives in order "to store the fading intellectual heritage of our forefathers" (Haavio 1935). ${ }^{4}$ This questionnaire, like the previous collections, was a continuum of the romantic assumption where purported 'folk' materials constituted an authentic language and literature. At the European level, collecting folklore from the 19th century onwards was part of nationalizing individual countries that needed to legitimize their own history and culture (Bendix 1997: 67).

From the end of the 19 th century until the 1960 s, academic folklore scholarship adopted the historic-geographic method, in which the main objective was to study the origin and history of folktales. Therefore, each folklore text had to be based on a large number of variants in order to reveal its origin and history. According to the instructions for collecting folklore, informants had to be asked their name, age, place of residence and the source of the folklore item. The collectors were not asked to note down the occupation or social class of the informant (Apo 1995b: 48). Therefore, the people who used those texts - songs, poems, proverbs and tales - in their everyday life were not of interest, since they were seen as only passive tradition bearers. Instead, what was important for the academic scholars and the folklore collectors at that time was the tradition itself, not the individuals using and creating meanings and living with them. The traits of the historic-geographic method are still evident in the Folklore 
Archives of the Finnish Literature Society. The collection of folklore genres is vast but many of the items have been stored without knowing the actual event or anything related to the social background.

The proverb database in the Folklore Archives of the Finnish Literature Society consists in its entirety of over 500,000 proverb texts. Each proverb text is on a single card and the file is for manual use. These cards are arranged in alphabetical order according to the first noun of a proverb or a proverbial saying (Laaksonen \& Saarinen 2004: 64). By a rough estimation, the total number of proverb cards that contain the words poor, poverty, pity or unfortunate is 6,000 . Since many of them are variants of others, the actual number of proverbs concerning poverty and the poor is notably less. For a proverb to be valid for the analysis in this paper, it must have at least two variants. Many of the proverbs often have 5 to100 variants in addition to an explanation of an informant for a specific proverb. However, almost as frequently, many proverbs are unique. From this very extensive material, I have omitted the proverbs that have been recorded only once.

The entire collection and, consequently, also this paper covers a variety of proverbial phrases: moral wisdoms, comments on life and phrases including comparison. Since the aim of the analysis is to study cultural knowledge, a detailed genre analysis of the proverbs - the question of whether a certain proverb is a proverb or merely a short comment - is irrelevant. When studying cultural knowledge - or 'folk ideas' - a researcher has to relinquish the nominal view of genre categories (Dundes 1972: 96).

In the proverbs tackled in this article, the perspective for poverty is most often that of the poor. At the time when poor relief was nearly completely absent, poverty was a matter of the poor, not of the nobility or clergy. Therefore, the proverbs may not have been universally true, but they were - just as Wolfgang Mieder has pointed out - correct in certain historical contexts and situations (Mieder 1993: xii). The imagery and the content of the proverbs have probably been part of the informants' everyday surroundings. However, a source that is almost as important is the imagery of earlier proverbs. Matti Kuusi has noted that traditional ideas, images and schemata have a decisive influence on the formation of proverbial sayings and a great majority of proverbs and sayings originate as analogical forms from earlier proverbs. According to Kuusi, folk aphorists saw their everyday milieu through the window of traditional symbology. Indeed, the traditional role division is rooted strongly in proverbs and, even more clearly, the dominance of the tradition directs their structural formation (Kuusi 1994: 142). The echoes of Matti Kuusi's view originated undoubtedly from the historic-geographic method but after exploring proverbs including 
other keywords than poverty (Stark 2011: 53), it is difficult to disagree with Kuusi at this point.

\section{FOLKLORE AS A WAY TO EXPRESS CULTURAL KNOWLEDGE}

According to Lauri Honko, there is no natural existence for folklore beyond performance. To him, folklore archives are nothing but collections of dead artefacts, arbitrarily limited texts that were generated under rather special, mostly non-authentic circumstances (Honko 1989b: 33). In this article, the focus is somewhat the opposite. I suggest that many folklore items, including proverbs, can be studied and analyzed without knowing the actual performance situation of the proverbs if the chosen sample is coherent by theme. Arvo Krikmann has pointed out that the bulk of proverbs represent kind of empiric laws or norms and communicative contexts serve merely as 'topical inductors' for proverbs (Krikmann 1996 [1994]). Therefore, proverbs used by individuals perform a significant part in containing, carrying, transmitting and communicating the varied products of the experience and knowledge of the people in their community.

Cultural knowledge is expressed in a great variety of different genres; yet, in this article, cultural knowledge is interpreted through the proverbs which include the words poor, poverty, pity and unfortunate. The basis for this article is the notion that a folklore genre dictates the limits of communication (Honko 1989a: 15). This means that cultural knowledge about poverty in the proverbs is represented in a specific, proverbial way. Precisely speaking, what is cultural knowledge and how should we understand it? First, cultural knowledge is about categorization, in other words, cultural knowledge enables people, 'informants', to categorize information, and second, it works as a theoretical notion for researchers.

People categorize their social environment; they do not merely think that they interact with individuals, but they tend to see them as members of more general classes, such as a family, social class, ethnic group, caste or gender (Boyer 2009: 296). Individuals rely on these shared understandings to comprehend and organize experience, including their own thoughts, feelings, motivations and actions, and the actions of other people (Quinn 2005: 2-3). The perceived world is thus presented as structured information rather than arbitrary and unpredictable attributes. Therefore, cultural knowledge is divided into categories in order to provide the maximum information with the least cognitive effort (Rosch 1978: 28). This is why people often use stereotypes and idealizations in their narratives and folklore. Accordingly, cognitive anthropology in particular has been 
interested in the forms and variability of cultural knowledge, 'folk knowledge', as well as their construction in specific contexts (D'Andrade 1995; Shore 1996).

The concept of cultural knowledge does not differ from the Dundesian concept of folk ideas, with the exception of the former being developed by cognitive anthropologists. In both concepts, the assumption is that people who belong to a given group or who have the same socioeconomic status, also share understandings of the world that have been learned and internalized in the course of their shared experiences. Furthermore, cultural knowledge is (or folk ideas are) embedded in words and stories and it is learned from other people and shared with them (Quinn 2005: 4).

The terms 'cultural models' or 'folk models' have been used to refer to the commonly shared cultural knowledge in a given social group. Folk models may be classified as models because they do not consist of merely separate fragments of knowledge but rather of world-ordering models that are either latent or manifested in them (Siikala 2002: 56). In this paper, poverty proverbs have been analyzed to determine answers to the following two questions: What connotations can be seen in the proverbs that include the words poor, poverty, pity and unfortunate? What sort of representations of social relations arise in poverty proverbs? These questions have been crucial in revealing the schematic structure that people use to communicate about rural poverty in Finland.

The poverty proverbs contain several ideas that are distinguished by their key words, imagery conveyed in metaphors, typical contexts of expression, and emotional twine (Strauss 1997: 371). I have generalized these ideas into models, basic beliefs on a higher abstraction level. These ideas have been crystallized into linguistic propositions but their denotation is only part of the constellation of semantic associations and mental images which are linked to the propositions in the mind of folklore users. Cultural models - or semantic bundles - linked to poverty proverbs are: 1) the signs of the poor; 2) the poor against the rich and their distinction; 3) answers to the question of how it feels to be a poor individual, and 4) the humane poor. I examine each of these four cultural models separately.

\section{THE SIGNS OF THE POOR}

From the corpus of 204 proverbs, many concern rather explicitly the appearance of the poor. In those proverbs, the social distinction between the people who are poor and those who are more affluent appears mainly by marking bodily differences. The characteristics that were visible to others were a skinny physique, dirtiness and ragged clothing. The two cultures of the rural environment, those 
of the landowners and the landless, were expressed not only by the size of their arable land and the extent of their property - livestock, agricultural equipment - but also by their different social manners. For example, the landless people acted differently. The landless poor ate quickly, whereas the masters had an easy and calm lunch break; the masters wore hats, whereas the landless people wore caps. Furthermore, clothing in general emphasized the difference between these two groups of people (Frykman \& Löfgren 1987: 260).

For the poor themselves, proverbs were a suitable way to express the agony of their everyday life. Poverty manifested itself in bodily signs. Slimness was a reason for laughing from within: The poor man has so little skin that when his eyes close, his asshole opens up. ${ }^{5}$ As to their physical traits, the poor were described by emphasizing their basic needs being merely physical. Swedish ethnologists Jonas Frykman and Orvar Löfgren have noted that in the eyes of the elite, poor people often appeared to be dirty, foul-smelling, unaware of "the correct code of behaviour", and vulgar (Frykman \& Löfgren 1987: 270). Living in poverty was a stigma and the authorities' attitude concerning poverty was primarily a matter of morals (Rahikainen 1993: 89). Did the poor know of the negative image that wealthier people had of them? According to the proverbs that include poverty-related keywords, the rural commoners knew well how the upper class criticized them. However, this did not mean that the poor would have agreed with the stigma attached to them.

Although Finland was a part of Russia since 1809, the institutional structure, including judicial, religious and local government authorities, had largely been established during the preceding Swedish period (Eloranta et al. 2006: 18). Therefore, for instance, the Finnish Poor Law in 1879 adopted its model from Sweden and in it the attitude toward poverty was hard (Rahikainen 1993: 90). The poorest people - usually the orphans, the sick and the elderly - were farmed out to landowning households at public auctions. Although the poor did not like being farmed out to households, there was even more antipathy to the strictly controlled poorhouses, which proliferated from the 1890s onwards (Rahikainen 2002: 169). People were generally expected to get along by themselves and in the poor society every man was accountable for himself and his family. The life of the poor was miserable and full of hardships and this is also demonstrated by metaphors in the proverbs. In order to cope with such uncertain livelihood conditions, the poor had to struggle to diversify their sources of income and food: Everything is growing in the poor man's sack. ${ }^{6}$ Often the poor's only belongings are what they carry: The poor man is like an open sack. ${ }^{7}$

The poverty proverbs utilize the hyperbole, an exaggeration, where both small and big blend as, for example, in the proverb: The poor man's granary has a hungry mouth. ${ }^{8}$ The exaggeration above consists of blending the images 
of the poor owning a food storage and of how starvation does not disappear despite the existence of the granary (because there is neither a granary nor food in it). It is therefore evident that the relief for the poor was too ineffective to prevent malnutrition. The miserable living standard of the poor was summarized by stating: The poor man's life is like wetness burning, or simply: The poor live in suffering. ${ }^{9}$

Some of the proverbs are humorous reflections on the desolateness of life. One of the most popular proverbs by number (more than 50 variants) deals with the advantages of being poor: The poor do not fall from high up, but from the broom to the floor. ${ }^{10}$ One of the informants of the proverb has explained this by stating that "if a poor person gets even poorer, it is not unknown to him because he has been at the bottom before". A similar idea can be found in the following proverb: The poor man doesn't fear becoming poor, the wet (man) doesn't fear the water. ${ }^{11}$ The life of the poor had either too much or too little; they had many children and illnesses and they had to move house often, but they also had little food, few clothes and a low life expectancy. This dichotomy is presented in a humorous way in the following proverb that is the answer to the question where one is from: The poor man can't afford to be from afar. ${ }^{12}$

Among the proverbial expressions concerning poverty, true poverty was seen as a mental state, not as being material or physical. The proverb Poor is the one who has no soul ${ }^{13}$ emphasizes how a person's true essence depends on wisdom, intelligence and righteous mind, not the amount of their material wealth. Often these types of proverbs have distinctly Christian overtones as, for example, in the proverbs: Even the masters have Lord, the wretched have souls, and: Even the poor man has his honour; even the wretched have God (Kuusi 1994: 146). ${ }^{14}$ In the poverty proverbs, the poor can have both literal and metaphorical meanings: it could refer either to a person who is in the state of material poverty, in other words, in absolute poverty, or to a person who has bad luck, is otherwise in a bad mental state, or is somehow pitiful.

In the Finnish poverty proverbs, 'a poor person' seems to be a synonym for an individual. This may reflect the shortages that existed in Finland until World War II. People who were agricultural labourers often lived in the landlord's household, although they did not belong to the family. Moreover, the majority of day-labourers in agriculture lived as cottagers on rented land or in rented rooms on the landlord's property (Peltonen 1995: 33). In the big picture, the majority of the landowning class was also relatively poor and only a small part of the whole population had an adequate standard of living. The concept of the poor is therefore polysemic, which means that related meanings of words form categories and the meanings bear familiar resemblances to one another (Lakoff 1987: 12). The word pity has an even stronger tendency for polysemy, 
since among the poor and sickly, it can refer to a bad person and its synonyms are 'unhappy', 'a lame duck', or 'a stupid one'.

Among the proverb users in the Finnish rural society, true poverty has concerned especially the insane, as the next proverb demonstrates: A poor one is not poor unless he is somewhat mad as well. ${ }^{15}$ Anthropologist Marianne Gullestad has pointed out that dichotomization and complementarization are processes that occur in ethnic and national movements but also in the issues of social identity (Gullestad 1996: 75). The Finnish autobiographies produced by common people born in the period of 1880-1930 had an oft-mentioned idea that was similar. Among the poor, people wanted to make a clear boundary between the poor and the insane (Stark 2011: 228). The poor did not want to become identified with other marginalized groups in the rural society even though both groups were regular users of the poor relief.

Many of the proverbs constitute norms, advice, or denials. Proverbs are often a suitable form of communication in domination relationships or in the relationship of a potential conflict (Finnegan 1981: 31). As Heda Jason points out, proverbs and oral literature in general serve as a connective element between the value system and the social systems by suggesting certain attitudes towards the society's values and its problematic points (Jason 1971: 619). The appearance and temper of the poor are described with pity, as a guideline for not repressing the ones who are already in a low social position in society as the next proverb suggests: Do not deride the poor man's child, he is already poor. ${ }^{16}$ In one of the proverb cards, the informant explained the idea of the proverb in the following manner: "If somebody wanted to tease someone and the other person realized this, he or she might have said this proverb to his/her teaser." As was mentioned above, the word poor might have referred to a naive or a gullible person as well.

According to social historian Marjatta Rahikainen, the purpose of the 1879 Poor Law was to make recourse to public assistance as difficult and as abhorrent as possible (Rahikainen 1993: 90). The mischief made by a poor one could have been criticized by a straightforward speech strategy as, for example, in the proverb: Beat if you like, the poor man's skin stands the pain. ${ }^{17}$ This proverb represents a figurative form of speech and the core idea of the proverb has obviously been conveyed by evoking the guilt of the malevolent. Severe conditions and misery were part of everyday life of the poor, and therefore, it was a recurrent, universal theme in the poverty proverbs, as the comparative collections of European proverbs indicate (Paczolay 2005: 132). 


\section{THE POOR AND THE RICH}

At the end of the 19th century, Finland was a poor but also a stratified and hierarchical society. Finland was a society of estates, which was a certain legally constituted class division of society. The two higher estates were the nobility and the clergy and the two lower estates were the burghers and the land-owning peasants. The gentry were few in number - they accounted for only $1.5 \%$ of the Finnish population in 1870 (Talve 1997: 30). Most of the population did not belong to an estate and had no political representation. Those who did not belong to an estate were cottagers and tenants of farms owned by others, farmservants, rural craftsmen, travelling salesmen, vagrants and the unemployed. Furthermore, the industrial workers living in towns and industrial parishes were not represented by the four-estate system. The population outside the estates was mainly behind the collected folklore because in its early decades the folklore collectors were interested only in the cultures of the lower classes, the people who were considered as 'folk'.

In the poor rural societies, landowning was seen as a primary source of livelihood. In estate societies, the ruling classes were those possessing land, and the ownership of land also meant the holding of political power (Wordie 1989: 6). Usually, the landowner who employed a number of rural labourers on his farm was at the top of the rural hierarchy. In Finland, the distinction between the landless and the landowning people became more marked at the end of the 19 th century when the size of the landless population rose dramatically due to the high birth rate and the decline of infant mortality (Eloranta et al. 2006: 16-17). At this point, by showing off their increased social power and prestige, the landowning groups began to eat and sleep in a different space from their agrarian workers (Haatanen 1968: 73).

The poverty mentioned in the proverbs is conveyed in terms of two polarities: the poor against the rich and the boundaries between those two. The poor exist only in contrast with the rich - a dichotomy whereby both actors are dependent on each other. Furthermore, the social relations, the conflicts in the social relations and the inversion of those relations as expressed in the poverty proverbs, are derived from the imbalance between the social classes. The boundaries between the rich and the poor were expressed not only in proverbs but also in other types of oral tradition, such as jests and fairytales. This has been explained by William Bascom as folklore representing a mirror of culture and incorporating descriptions of the details of social institutions as well as the expressions of attitudes (Bascom 1965: 284).

The proverb informants have predominately been the poorest in the absolute and relative terms of poverty in their own society. By definition, absolute 
poverty is a lack of basic human needs, such as clean water, nutrition, clothing, shelter, health care and education. In contrast, relative poverty is the condition of having fewer resources or less income than others within a society (Townsend 1979: 31-33). By belonging to the category of the poor, people were aware of the concept of prosperity. In proverbs, the juxtaposition between the poor and the rich is reflected not by comparing the breadth of welfare, but by marking one's own actions and personality. In this context, without question, the poor and the rich are not on an equal footing. The next proverb introduces the idea of the distortion of social strata: The rich man hides his richness, but the poor man can't hide his poverty. ${ }^{18}$

In spite of their lower social status, the poor were believed to get on better than the rich. Low status results in more joys and happiness than those at a higher level of status enjoy: The poor man is rich when his belly is full, but the rich man has much to worry about, for he fears becoming poor..$^{19}$ This perspective where the poor were portrayed as courageous, kind and ingenious in contrast to the lazy and self-indulgent antagonists who were high-born and wealthy, is also familiar from fairytales (Apo 1995b: 208, 215, 218).

The poverty proverbs are composed of formulas, the forms of which can be constructed like many aphorisms that stress the shared fates of opposites (Kuusi 1994: 143). The confrontation between the poor and the rich resulted in a dead heat and the resistance against one's own low social position was futile since the social class offered obvious advantages, as the next proverb claims: The rich people drink, the strong ones fight and the poor people transfer homebrew by the horse-drawn carriage. ${ }^{20}$ In other words, the poor made use of the rich people's vices that were provided by their prosperity. Advantages produced disadvantages that, in turn, produced advantages.

\section{DISTINCTIONS BETWEEN THE POOR AND THE RICH}

Cultural knowledge of poverty was also verbalized by basing the proverbial idea on the higher status of the rich people. Anthropologist James Scott uses the term mystification, which is something that subordinate classes do to themselves by justifying the force of circumstances, i.e., "the naturalization of the inescapable" (Scott 1985). The means and ways of surviving are justified simply by using common sense. In this type of proverb, power is viewed from below upwards.

In Finland, land ownership was of vital importance for cultural boundaries. One of the most common ways in which the rural poor resisted their landlords and the upper classes in general was by moralizing about how their lifestyles and practises deviated from those of the poor (Frykman \& Löfgren 1987: 148). 
For the lower classes - the representatives of the common folk - the existing imbalance of social boundaries was expressed by changing the perspective. Proverbs therefore addressed critique indirectly. One's own low status was elicited from the position of the rich: He doesn't acknowledge the poor, nor does he speak to the ugly. ${ }^{21}$ Issues related to poverty, such as begging and the associated stigma, were argued by coercion: I don't need to, but a poor man's child must. ${ }^{22}$ The landowners in the impoverished society were usually well aware of their higher status and did not hesitate to show it if needed. James Scott uses the term 'weapons of the weak', referring to the hidden verbal and practical acts of resistance in contexts where the 'weak' cannot afford to openly confront power holders (Scott 1985: xvi).

Poverty proverbs can be interpreted as manifestations of weapons of the weak, just as they are representations of the culture of contestation. This means that the subordinate people resist the generally applied cultural forms of the dominant classes by seeing things differently. This notion was first introduced by anthropologist Luigi Lombardi-Satriani, who traced out the idea that everyday reality provides an ample sounding board for the critical social attitudes manifest in different ethnographic descriptions and folklore genres (LombardiSatriani 1974: 103-105). The term contestation refers to the context'of adducing opposing testimony' towards the hegemonic culture, that is, the culture that is defined by the people in power in a given historical society. This resistance is manifested in the adoption of different ways of thinking and behaviour by those in power that produce the dominant ideologies in the society.

The different views on poverty that are expressed in the proverbs can be manifested by using personification. Personification is a description of an object as being a living person or animal (Lakoff \& Johnson 1980: 33). In these proverbs, poverty can act independently and it can cause bad consequences, such as is the case in the following proverb: When poverty comes in at the window, love goes out of the door..$^{23}$ One could argue that this proverb is more crucially about love but, in addition, it concerns the ideal love which is rooted in the questions of one's living standards and the avoiding of poverty. Poverty in the proverbs refers to a lack of material and physical needs but is also expressed in the setting of family relations and paring. Personified poverty represents the image that was presumably also familiar to the better-off people in the rural society because such proverbs express notions of deprivation that are somehow universal. Moreover, poverty causes disagreements inside families and marriage relationships.

One of the universalities of poverty is that it has a visual aspect. The poor received better social financial support if they behaved humbly and gave the appearance of a ragamuffin (Stark 2011: 323). By being categorized as the poor, 
people were expected to be, act and verbalize in a certain way. Sometimes this performance probably went too far, which resulted in other poor and even the better-off people's statement: There, poverty and pomp pull the cat's tail. ${ }^{24}$ The personified poverty in these proverbs was a way of criticism in the contexts where straightforward sarcasm would have been too cruel. One example of this is the visual stress on poverty: the poor with their humble behaviour and filthy appearance evoked more empathy from the better-off people and therefore more welfare money.

Personification in language makes it easier to understand abstractions and also to elucidate causality in a historical context. The next story was originally a proverb but it has been attached to an additional story:

When poverty starts to rule a house, it first travels along the fences to the mansion, then it goes into the main room, and once in there, it goes to the beams where the kindling chips are stored. From there it goes to the bread crate and lands on the table.

As the preceding story illustrates, poverty imagery can act independently. Another variant expresses this idea more succinctly: When poverty arrives, it arrives in nine ways. ${ }^{25}$

\section{HOW DOES IT FEEL TO BE IN NEED?}

Poverty defines one's actions - social relations and the expressions of oneself. One theme of the poverty proverbs concerns the cruel aspects of the estate society and the status of the poor within this society. This semantic group includes advice as well as the dos and don'ts for the poor. Many of the proverbs describe the gloominess of life when living in poverty as, for example, in the proverb: The poor one is created to ramble, the crippled one to wander.$^{26} \mathrm{Just}$ as the definition of absolute poverty, proverbs also identify the idea of the worst state of poverty, which stands aside simply by the nutrition being on offer: The poor man is rich when his belly is full. ${ }^{27}$ Living in poverty is troublesome, as challenging as gaining and maintaining prosperity: Poverty is not for the poor to rule. ${ }^{28}$ More realistic are the proverbs that describe the everyday life challenges for the poor as, for example, in the proverb: How can the poor man fart, if he doesn't even have anything to eat? and: How can the poor man buy, when one pocket is empty and the other pocket has nothing in it?29 The latter proverb has a version that both exalts the unfortunate and mirrors the egalitarian views in the verbal use of ordinary folk: How can the poor man buy if he only has a soul? ${ }^{30}$ 
Although poverty in proverbs can be interpreted as a representation of a culture of contestation - that is, the poor recognized the positive aspects of living in poverty - the lower social status of the poor was also acknowledged. The latter was a negative aspect of poverty - the poor person was a nobody: The poor man is looked down upon, his shoes are fed to the dogs ${ }^{31}$ In addition to physical appearance, the poor were recognized by their lack of social networks: No one is a friend of the poor man..$^{32}$ Also, the unfortunate were not the most welcomed guests at social gatherings. The low status of the poor manifested unofficial rules and codes that made the social distinction between the rich and the poor clearer. As E. P. Thompson has observed, the ruling class control in the estate societies was located primarily in cultural hegemony, and only secondarily in an expression of economic power (Thompson 1991: 43). The status of the poor in the Finnish rural society produced a logic of action that required explanations. By explaining their views, people became aware of the hierarchies and existing social categories. Begging was one behavioural act that was rationalized: The poor man eats when he gets. ${ }^{33}$ It is simply rational to eat what one is being offered, which is also the following underlying idea in the proverb: The poor man is devoid of everything. ${ }^{34}$

The actions of the poor were restricted by the limitations that were interpreted either negatively as coercion, or positively, with humour. Coercions of the ruthless circumstances are being described, for instance, in the proverb: There is no law for the poor. ${ }^{35}$ Life was harsh and it was better to live one moment at a time. The differences between the poor and the rich were also visible in the ways that some things were possible and even in the interests of the rich, but not of the poor. For example, the idea of the proverb: The poor man has time to pass away, but not to suffer ${ }^{36}$ is the costs of illnesses that were a reason for the poor not to go to a doctor (Urponen 1994: 237). The limited opportunities for the poor were not always interpreted negatively - sometimes one's distress was being laughed at. Although poverty was a serious, non-ridiculed state of affairs, speaking of it with humour enabled the speakers to comment on the existing social hierarchies. For instance, the minimal aspect of one's own actions is described by the following proverb: The poor man's feast doesn't run late, starts in the evening, ends in the evening. ${ }^{37}$

How does it feel to be in poverty? Quite often poverty proverbs offer reflection on the essence of poverty. In the estate society, poverty was regarded as a personal weakness. The estate society was justified by believing it was God's will and the social position of a person in society reflected their capability and nature (Frykman \& Löfgren 1987: 164). The producers of the poverty proverbs were mainly people from the social underclass and therefore the most common advice for tackling poverty was not to be ashamed of it. The proverbs Poverty is 
no disgrace, but it is a great inconvenience and Poverty is not a crime $e^{38}$ bring out the idea of not blaming oneself for poverty. In addition, the accusations that the poor people are lazy and good-for-nothing are contested in proverbial speech, as in the following proverb known in many cultures: After all, poverty is not a pleasure to anybody. ${ }^{39}$ According to the informant of the proverb above, "the saying is told if one has encountered poverty, meaning that want of something itself is a source for sorrow and misery and not for joy to anybody".

In spite of the poor's miserable life, living in poverty is described - again - in humorous terms. One of the most popular poverty proverbs by the number is the extended variant of the proverb: Poverty is no joy to anybody but I have laughed at it. ${ }^{40}$ In the Finnish Folklore Archives collection, the more variants a proverb has, the more likely there are informants' explanations for the proverb. The proverb above has been explained by one informant as follows: "Even though poverty is a miserable state of affairs, the poor have a right for joy and sometimes that joy can be poverty itself". The proverbial poverty humour arises from the fact that people have nothing and it produces embarrassing and uncomfortable situations. For example, measliness is a reason for laughing: The poor man gets his joy from farting or: To be poor and thin is good for a man. ${ }^{41}$ Furthermore, one recurrent theme in the poverty proverbs is farting. Jonas Frykman and Orvar Löfgren argue that rules of cleanliness related to the bourgeoisie lifestyle at the end of the 19th and beginning of the 20th centuries were concerned with the triumph of culture over nature. In other words, people who behaved in a sophisticated way held a better position in society than those who appeared more 'natural'. By taming the animal within - emotions, organic functions, and sexuality - a person became cultured (Frykman \& Löfgren 1987: 172-173). The elite was more worried about the common people's morals and behaviour than about hunger (Haapala 1986: 399). The poor were familiar with the upper- and middle-class values of cleanliness and order, but at the same time, they found this life-style difficult to realize in their own cultural context. Moreover, the poor actively contested the views of the elite by showing off the manners that attracted condemnation, such as farting and belching (Apo 1995a: 167).

People representing a certain status are usually expected to behave and express their aims verbally in specific ways (e.g. Shuman \& Bohmer 2004: 407). In the Finnish estate society, the socially lowest groups were expected to be quiet and humble: Poverty tells one to be quiet..$^{42}$ Often, instead of advising one how to behave, proverbs warn against misbehaving (Jason 1971: 619). For example, folklore warned against being poor and too proud: There is nothing more annoying than a poor man who is proud. ${ }^{43}$ The subjection relations in rural Finland were not simply defined by the elite from above downwards, where the lower classes would have been the subordinate or victims of the people in 
power. On the contrary, the lower class preferred to behave in a certain way in relation to the ruling class in order to get a job and to keep the wolf at bay. The landowning peasants hired their landless counterparts to work on their land and therefore it was in the poor people's interests to get along with their masters. Being simple and timid evoked the least irritation among the landowning peasants (Stark 2011: 121). This historical context is probably the background to the proverbs emphasizing the humble nature of the poor.

\section{THE HUMANE POOR}

Although in proverbial representations the poor considered themselves too small in relation to the elite, they were not voiceless in their society. By internalizing their place in their own society, the poor did not fully accept the hegemony of the upper class people. Just as in African proverbs, the emphasis in the Finnish poverty proverbs is on the egalitarian perception based on creation (Kimilike 2006: 234). As physical beings, the poor interpreted themselves as being equal to the landowning peasants, burghers and officials. This affected the senses and the desire to be similar to the hegemonic classes: The poor man's mouth tastes sweet. The same idea is expressed in the proverb: Although he's poor, his mouth isn't made of birch bark. ${ }^{44}$ Moreover, economic imbalance led to different cultural codes that were presented in social situations. The way a dead person was consigned to the grave revealed the social position of the deceased: When a poor man dies, he is buried in a shallow grave..$^{45}$ Despite the funeral customs, the dead body of the poor person had to be treated with respect: No one is so poor that he can't be carried in a coffin. ${ }^{46}$

The humane aspect of the poor in the poverty proverbs encourages people to treat the unfortunate well. One of the most popular proverb guides is: Don't sneer at the poor man's sled for yours is made of alder ${ }^{47}$ Here, an informant explained the proverb so that "it was said as a critique to somebody who had spoken of the work and deeds of other people with despise". Another informant's explanation to the proverb was "not to mock other people's lives because your own life is not that good, either". Laura Stark-Arola has noted that envy, anger and desire in the 19th century Finnish countryside were not seen as emotions but rather as forces that only magic or aggressive anti-actions could have clamped down. Some of the magic actions were the belief of the evil eye, the laws of sympathy and contagion and the various mechanisms of magical harm such as curses and 'spoiling'. They all represent cultural knowledge that reverberates through all aspects of social life. According to the folklore of the Finnish magic rituals, envy and harmful thoughts were not under the mastery 
of the people themselves, but were uncontrolled forces that were self-acting (Stark-Arola 2002:68).

In rural Finland, the poor were considered worthy of aid in order to avoid magical curses that they could have handed down or that could have happened anyway without a seemingly known benevolent actor. Some proverbs convey the idea of granting aid that is straight from the Bible (Kuusi 1994), for example: Do not enclose your hand from the poor, and: He who has pity on the poor lends to the Lord. During the period in Finland when the welfare benefit system was undeveloped, the poor expected the better-off people to make a greater contribution to the distribution of material wealth. Aiding pertained also to one's closest relatives: Do not disdain poor relatives and small wounds. ${ }^{48}$

Even though some of the poverty proverbs are obviously connected to magic beliefs, there is a clear link to the political ideas about class relations in proverbial speech. According to these views, misery and agony that stem from poverty emerge as the consequences of the uneven distribution of wealth. The proverb He did not die of poverty but of cold and hunger ${ }^{49}$ sets the idea of poverty on the level of causality, asking implicitly about the circumstances where people are required to live. The political aspect of the poverty proverbs concerns the idea of prosperity by leaving economic worries behind as, for example, in the proverb: Let the poor man benefit, the ailing one heal..$^{50}$ In a poor society, in terms of material goods, everyday actions were restricted and this was well acknowledged by the poor. The wish for something better in one's life was expressed either by emphasizing material needs, as in the proverb: Where the poor one loses except wishing to become a rich one, or mental values as, for example, in the proverb: Even the poor man cannot be denied high ideals. ${ }^{51}$

\section{CONCLUSIONS}

Finland underwent the process of modernization and economic growth relatively late. Nowhere else in Western Europe social and technological changes occurred as rapidly as in Finland - during the span of a mere lifetime. Until World War II, most of the Finns lived in a high-risk society in which there were few institutions to guarantee their safety and well-being. Social and economic conditions, and the changes in them, have undoubtedly had a great impact on folklore and popular thought.

Rural society and the poverty in it have been thoroughly studied by historians and social politicians. In spite of our view of poverty in the past, the phenomenon has still been inadequately described. In previous poverty studies, the poor themselves hardly ever had a direct opportunity to explain what 
it was like to be poor. Therefore, proverbs are an excellent way to look inside societies to get a glimpse of the past and the people in them. Proverbs reflect attitudes, norms and intentions that people are interested in within the social boundaries of their own society. In order to study proverbs at their ideational level, a researcher needs sufficient knowledge of the specific features that concern proverbs as a genre.

As hints of cultural knowledge, proverbs originally produced orally are not products of individual minds isolated from society but strategic responses to a continuous chain of narrative flow arising in everyday social life. Folklore created by people who were members of neither the nobility nor the priesthood does not recount past events, but instead offers clues to the crucial cultural themes and the values of common people in the past.

\section{ABBREVIATIONS}

HAKS = Hämeenlinnan alakansakouluseminaari $[$ Hämeenlinna Teacher Training College $]^{52}$

$\mathrm{KRA}=$ Kansanrunousarkisto [Folklore Archives of the Finnish Literature Society]

$\mathrm{KRK}=$ Kalevalan riemuvuoden kilpakeräys [Collection contest in honour of the 100th anniversary of Kalevala]. Helsinki: Finnish Literature Society

$\mathrm{KT}=$ Kansantieto ja pienet keräelmät [Answers to the questionnaire from the journal 'Folk Knowledge' and small collections]. 1936-to present. Helsinki: Finnish Literature Society

VK = Vähäisiä keräelmï̈ [Minor collections]. 1900-1930s. Helsinki: Finnish Literature Society

\section{ARCHIVAL SOURCES}

Folklore Archives of the Finnish Literature Society in Helsinki (proverb-cards: köyhä, köyhyys, vaivainen)

\section{NOTES}

1 The keywords in Finnish are: köyhä (poor), köyhyys (poverty), vaivainen (pity, crippled, unfortunate, wretched). The archive is located in Helsinki.

2 Collecting folklore was a grassroots activity in the making of the Finnish nation where one of the many aspects was the political integration of Swedish speakers and Finnish speakers. About the Fennoman nationalists and their symbolic turn to the 'people', see, e.g., Anttonen 2005: 162. 
3 Matti Kuusi has listed by name the most active collectors who have sent over 1,000 proverbs to the Folklore Archives of the Finnish Literature Society; see Kuusi 1997: IX-X. The proverbs I have used are mainly from the same collectors.

4 Tarkoituksena on kansan itsensä avuin saada tuleville ajoille säilytetyksi esi-isiemme henkisen perinnön viimeiset sirpaleet, jotka vielä ovat säilyssä kansamme muistissa.

5 Köyhääs on niin vähä nahkua, ku silmät mänee kii, ni pers jää auki. KRA. Hartola. A. Heino 310.1935 .

${ }^{6}$ Kaikki köyhän säkissä itää. KRA. Pohjois-Savo. J. Härkönen VK 23:367.1904.

7 Köyhä on yhtenä säkkinä. KRA. Paltamo. O.A.F. Lönnbohm 4401.1920.

8 Köyhän aitta on suuta täynnä. KRA. Forssa. K. Erkko KT 44:203.1936.

9 Köyhän elämä on kuin märkä palais. KRA. Kaustinen. Heikki Savo KT 176:317.1938; Köyhä kituin elää. KRA. Viipurin pit. P. Vauhkonen VK 107:491.1922.

${ }^{10}$ Ei köyhä korkialta kaadu, luudan päältä lattialle. KRA. Ilmajoki. J. Pirilä 227.1885.

${ }^{11}$ Köyhä ei pelkää köyhtymistä, märkä ei kastumista. KRA. Sulkava. HAKS 6486.1938.

${ }^{12}$ Ei köyhän kannata kaukaa olla. KRA. Tervo. Anni Heimonen KT 88:248.1936.

${ }^{13}$ Sehän köyhä on, jolla ei ole sielua. KRA. Parikkala. Ida Mikkonen 14.1908.

${ }^{14}$ Herra on herrallakin, vaivasellakin Jumala. Karstula. Rutuna H. E. 108.1891; On köyhälläkin kunniansa, vaivaisellakin Jumala. Suistamo. HAKS 16662.1943.

${ }^{15}$ Ei kööh ol ilman kööh, ete ol vähä hull kans. KRA. Uusikirkko. Jalo Numminen 237.1916.

${ }^{16}$ Ei saa narrata köyhän lasta, se on köyhä ilmankin. KRA. Valkjärvi. A.G. Andersson 364.1902.

${ }^{17}$ Lyö jos lystää, kyllä köyhän nahka kestää. KRA. Kemijärvi. Paloheimo A. 768.1909.

${ }^{18}$ Rikas salaa rikkautensa, vaan köyhä ei voi salata köyhyyttään. KRA. Kärsämäki. Jalmari Pyrrö VK 77:104.1915.

19 Silloin on köyhä rikas, kun on maha täys, mutta rikkaalla on suuri huoli, kun pelkää köyhtyvänsä. KRA. Laukaa. J.G. Oksanen 207.1892.

${ }^{20}$ Rikkaat juo, väkevät tappelee ja köyhät ajaa sahtia. KRA. Kuhmalahti. HAKS 18664.1943.

${ }^{21}$ Ei tunne köyhää eikä puhu rumien kanssa. KRA. Piikkiö. HAKS 17852.1943.

${ }^{22}$ Mun ei tarvihe, mutta köyhän lasten täytyy. KRA. Nurmes. Aino Hirvonen 3064.1956.

${ }^{23}$ Köyhyys tulee ikkunasta sisää, rakkaus menee ovesta ulos. KRA. Nurmes. Impi Ollilainen KT 153:10.1937.

${ }^{24}$ Siinä köyhyys ja komeus vetävät kissanhäntää. KRA. Johannes. HAKS 25820.1944. 
${ }^{25}$ Kun köyhyys rupeaa alistamaan taloa, tuloo se ensin aitoja pitkin kartanoihin, sitten se menee tupaan ja siellä ensiksi päreorsille. Sieltä se menee leipähäkkiin ja sieltä se purottaa pöyrälle itsensä. KRA. Veteli. Väinö Tuomaala 3086.1949; Kun köyhyys tuloo, niin se tuloo yhdeksää tietä. KRA. Härmä. J.O. Ikola 3422.1922.

${ }^{26}$ Luotu köyhä kulkemaan, vaivainen vaeltamaan. KRA. Ylihärmä. Antti Kangas VK 35:538.1890.

${ }^{27}$ Silloin on köyhäki rikas ko on kupu täysi. KRA. Rovaniemi. M. E. Perunka VK 74:89.1927

${ }^{28}$ Köyhyys se ei ole vähävarainen hallittava. KRA. Kiihtelysvaara. Iida Vallaskangas 444.1911.

${ }^{29}$ Mistäpäs köyhä pierasee kun ei oo mitä nielasee. KRA. Lehtimäki. Aaro Vallinmäki 1186.1914; Millä köyhä ostaa, toinen tasku on tyhjä, toises ei mitään. KRA. Noormarkku. Fr. Lindgren 659.1892.

${ }^{30}$ Millä se köyhä ostaa, kun sillä ei ole kuin sielu. KRA. Vieremä. HAKS 20357.1943.

${ }^{31}$ Ylen köyhä katsotaan, kengät koiralle syötetään. KRA. Nurmes. Aino Hirvonen 3431.1956.

${ }^{32}$ Ei köyhän kanssa ole kukaan tuttava. KRA. Ylihärmä. Isak Korpi 332.1900.

${ }^{33}$ Silloin köyhä syö, kun hän saa. KRA. Pori. J. Friman 17.1889.

${ }^{34}$ Kaikkia vaivainen vailla. KRA. Rautalampi. Kuopion lyseon toverikunta XXXVIII:76.1889.

${ }^{35}$ Ei köyhällä lakia ole. KRA. Orivesi. Hugo Hörtsänä 2270a.1953.

${ }^{36}$ Kyllä köyhä kuolla joutaa, mutta ei sairastaa. KRA. Ylihärmä. Isak Korpi 17.1900.

${ }^{37}$ Ei köyhän pitoja pitkälle pidetä, illalla alkaa, illalla loppuu. KRA. Eräjärvi. J. Tyyskä 1428.1908.

${ }^{38}$ Ei köyhyys oo mikään häpiä, se on vaan joku muu onnettomuus. KRA. Ylihärmä. Vaasan suomalaisen lyseon konventti IV:840.1888; Ei köyhyyskä ole mikkään rikos. Alastaro. E. Vihervaara 2156.1911.

${ }^{39}$ Eihän tää köyhyys ole ilo kellekään. KRA. Mäntyharju. J. Hotinen 1053.1931.

${ }^{40}$ Köyhyys ei oo ilo kellenkään, mutta minua se vaan naurattaa. KRA. Kivijärvi/Karstula. Jalmari Leppänen 390.1937.

${ }^{41}$ Köyhän ilo, kun pieree ja nauraa. KRA. Naantali. P. Nummelin 1203.1892; Köyhänä ja laihana on ihmisen hyvä olla. KRA. Teisko. T. Aatola VK 1:9.1912.

${ }^{42}$ Köyhyys käskee olemah hiljan. KRA. Iitti. T. Puttila 178.1887.

${ }^{43}$ Ei mikään niin harmita, kun köyhä, joka on ylpiä. KRA. Uskela. Väinö Kallio 2951.1912.

${ }^{44}$ Köyhänkin suu makean maistaa. KRA. Jurva. U. J. Tarkkanen VK 97:381.1890; Eihän se köyhänkä suu tuohest o. KRA. Orimattila. F. A. Hästesko 521.1907. 
${ }^{45}$ Kun köyhä kuoloo, niin matalaan maahan pannaan. KRA. Korpiselkä. I. Rikkonen 570.1909 .

${ }^{46}$ Ei niin köyhää kuollutta, ettee arkussa kantta. KRA. Iisalmi. Elma Saarinen KT 284:456.1957.

${ }^{47}$ Elä pilkkoo köyhän kelkkoo, leppäne se on ommais. KRA. Liperi. Tommi Korkala 1087.1939

${ }^{48}$ Köyhää sukuu ja pientä haavaa ei pidä ylenkatsoman. KRA. Nummi. Matilda Österberg 17.1887.

${ }^{49}$ Ei se köyhyytee kuollu, mutt villuu ja näläkää. KRA. Savonlinna. Aleks Seppänen 450.1936 .

${ }^{50}$ Soishan köyhä hyötyvänsä, poteva paranevansa. KRA. Jääski. E. Paajanen VK 70:29.1903.

${ }^{51}$ Ei köyhääkää oo kielletty korkeist aatoksist. KRA. Kivennapa. Oma Martti Paavolainen 373.1950 .

52 The college of education whose students collected folklore and handed it over to the Folklore Archives of the Finnish Literature Society.

\section{REFERENCES}

Alanen, Ilkka 1995. Finland as a Peasant Society and the Agrarian Reforms. In: Leo Granberg \& Jouko Nikula (eds.) The Peasant State. The State and Rural Questions in 20th Century Finland. Rovaniemi: University of Lapland, pp. 42-53.

Anttonen, Pertti 2005. Tradition through Modernity. Postmodernism and the NationState in Folklore Scholarship. Helsinki: Finnish Literature Society.

Apo, Satu 1995a. Naisen väki. Tutkimuksia suomalaisten kansanomaisesta kulttuurista ja ajattelusta. [Women's Force: Studies of Finnish Folk Culture and Popular Thought.] Helsinki: Hanki \& Jää.

Apo, Satu 1995b. The Narrative World of Finnish Fairy Tales. Structure, Agency, and Evaluation in Southwest Finnish Folktales. Helsinki: Academia Scientiarum Fennica / Suomalainen Tiedeakatemia.

Bascom, William 1965 [1954, http://dx.doi.org/10.2307/536411]. Four Functions of Folklore. In: Alan Dundes (ed.) The Study of Folklore. Englewood Cliffs, N. J.: Prentice-Hall, Inc., pp. 279-298.

Bendix, Regina 1997. In Search of Authenticity. The Formation of Folklore Studies. Madison, Wisconsin: The University of Wisconsin Press.

Boyer, Pascal 2009. Cognitive Predispositions and Cultural Transmission. In: Pascal Boyer \& James V. Wertsch (eds.) Memory in Mind and Culture. Cambridge: Cambridge University Press, pp. 288-320, http://dx.doi.org/10.1017/CBO9780511626999.018.

D’Andrade, Roy G. 1995. The Development of Cognitive Anthropology. Cambridge: Cambridge University Press. 
Dundes, Alan 1972 [1971, http://dx.doi.org/10.2307/539737]. Folk Ideas as Units of Worldview. In: Américo Paredes \& Richard Bauman (eds.) Toward New Perspectives in Folklore. Austin: University of Texas Press, pp. 93-103.

Eloranta, Jari \& García-Inglesias, Concepción \& Ojala, Jari \& Jalava, Jukka 2006. On the Road to Prosperity: An Introduction. In: Jari Ojala \& Jari Eloranta \& Jukka Jalava (eds.) The Road to Prosperity. An Economic History of Finland. Helsinki: Suomalaisen Kirjallisuuden Seura, pp. 15-31.

Finnegan, Ruth 1981. Proverbs in Africa. In: Wolfgang Mieder \& Alan Dundes (eds.) The Wisdom of Many. Essays on the Proverb. Madison, Wisconsin: The University of Wisconsin Press, pp. 10-42.

Frykman, Jonas \& Löfgren, Orvar 1987. Culture Builders. A Historical Anthropology of Middle-Class Life. New Brunswick, New Jersey \& London: Rutgers University Press.

Granbom-Herranen, Liisa 2010. Women's Place in Finnish Proverbs from Childhood. Folklore. Electronic Journal of Folklore, Vol. 46, pp. 95-110, http://www.folklore. ee/folklore/vol46/granbom.pdf, last accessed on February 1, 2013.

Gullestad, Marianne 1996. Everyday Life Philosophers. Modernity, Morality, and Autobiography in Norway. Oslo \& Stockholm \& Copenhagen \& Boston: Scandinavian University Press.

Haapala, Pertti 1986. Tehtaan valossa. Teollistuminen ja työväestön muodostuminen Tampereella 1820-1920. [In the Light of the Factory. Industrialization and the Formation of the Working Class in Tampere, Finland, 1820-1920.] Tampere: Osuuskunta Vastapaino.

Haatanen, Pekka 1968. Suomen maalaisköyhälistö tutkimusten ja kaunokirjallisuuden valossa. [Rural Proletariat in Finland in the Light of Scholarly Research and Literature.] Porvoo \& Helsinki: WSOY.

Haavio, Martti 1935. Kalevalan riemuvuoden kilpakeräys. [The Collection Competition of the Kalevala Jubilee.] Helsinki: Suomalaisen Kirjallisuuden Seura.

Honko, Lauri 1989a. Folkloristic Theories of Genre. In: Anna-Leena Siikala (ed.) Studies in Oral Narrative. Helsinki: Suomalaisen Kirjallisuuden Seura, pp. 13-28.

Honko, Lauri 1989b. Methods in Folk Narrative Research. In: Reimund Kvideland \& Henning K. Sehmsdorf (eds.) Nordic Folklore: Recent Studies. Bloomington: Indiana University Press, pp. 23-39.

Jason, Heda 1971. Proverbs in Society: The Problem of Meaning and Function. Proverbium, Vol. 17, pp. 617-623.

Kimilike, Lechion Peter 2006. An African Perspective on Poverty Proverbs in the Book of Proverbs: An Analysis for Transformational Possibilities. Unpublished PhD thesis. University of South Africa, uir.unisa.ac.za/bitstream/handle/10500/2372/ thesis.pdf?sequence=1, last accessed on February 1, 2013.

Krikmann, Arvo 1996 [1994]. The Great Chain Metaphor: An Open Sesame for Proverb Semantics? Folklore. Electronic Journal of Folklore, Vol. 1, pp. 74-83, http://www. folklore.ee/folklore/nr1/gcm.htm, last accessed on February 1, 2013.

Kuusi, Matti 1994. Mind and Form in Folklore. Selected articles. Helsinki: Suomalaisen Kirjallisuuden Seura.

Kuusi, Matti 1997. Sananlaskut ja sananparsikokoelmat. [Proverbs and Proverb Collections.] In: Sananlaskut. 15904 sananlaskua Kansanrunousarkistosta. [Proverbs. 
15904 proverbs from the Folklore Archive.] Helsinki: Suomalaisen Kirjallisuuden Seura, pp. V-XI.

Laaksonen, Pekka \& Saarinen, Jukka 2004. Arkiston avain. Kansanrunousarkiston kortistot, hakemistot, luettelot, lyhenteet. [Key for the Archive. Cards, Indexes, Lists, Abbreviations of the Folklore Archive.] Helsinki: Suomalaisen Kirjallisuuden Seura.

Lakoff, George 1987. Women, Fire, and Dangerous Things. What Categories Reveal about the Mind. Chicago \& London: The University of Chicago Press.

Lakoff, George \& Johnson, Mark 1980. Metaphors We Live By. Chicago: The University of Chicago Press.

Lombardi-Satriani, Luigi 1974. Folklore as Culture of Contestation. Journal of the Folklore Institute, Vol. 11, No. 1/2, pp. 99-121, http://dx.doi.org/10.2307/3813943.

Mieder, Wolfgang 1993. Proverbs Are Never Out of Season. Popular Wisdom in the Modern Age. New York \& Oxford: Oxford University Press.

Paczolay, Gyula 2005. Ezër magyar közmondás és szólás - angol, észt, finn, némët fordítással és mëgfelelókkel, latin forrásokkal. [1000 Hungarian proverbs together with their translations and equivalents in English, Estonian, Finnish and German and Latin sources.] Budapest: Bárczi Géza Kiejtési Alapítvány.

Peltonen, Matti 1995. From Peasant Holdings to Family Farms. Impact of the Agricultural Depression of the 1880s-1910s on Finnish Peasant Farming. In: Leo Granberg \& Jouko Nikula (eds.) The Peasant State. The State and Rural Questions in 20th Century Finland. Rovaniemi: University of Lapland, pp. 23-41.

Quinn, Naomi 2005. How to Reconstruct Schemas People Share, from What They Say. In: Naomi Quinn (ed.) Finding Culture in Talk. A Collection of Methods. New York: Palgrave Macmillan, pp. 35-81.

Rahikainen, Marjatta 1993. From the Poor Laws to the Welfare State. In: Marjatta Rahikainen (ed.) Austerity and Prosperity. Perspectives on Finnish Society. Lahti: University of Helsinki, Lahti Research and Training Centre, pp. 88-103.

Rahikainen, Marjatta 2002. Compulsory Child Labour: Parish Paupers as Indentured Servants in Finland, c. 1810-1920. Rural History, Vol. 13, No. 2, pp. 163-178, http://dx.doi.org/10.1017/S0956793302000092.

Rosch, Eleanor 1978. Cognition and Categorization. In: Eleanor Rosch \& Barbara B. Lloyd (eds.) Cognition and Categorization. Hillsdale, New Jersey: Lawrence Erlbaum Associates, pp. 27-48.

Scott, James C. 1985. Weapons of the Weak. Everyday Forms of Peasant Resistance. New Haven \& London: Yale University Press.

Shore, Bradd 1996. Culture in Mind. Cognition, Culture, and the Problem of Meaning. New York \& Oxford: Oxford University Press.

Shuman, Amy \& Bohmer, Carol 2004. Representing Trauma: Political Asylum Narrative. Journal of American Folklore, Vol. 117, No. 466, pp. 294-414.

Siikala, Anna-Leena 2002. Mythic images and Shamanism. A Perspective on Kalevala Poetry. Helsinki: Academia Scientiarum Fennica / Suomalainen Tiedeakatemia.

Stark-Arola, Laura 1998. Magic, Body and Social Order. The Construction of Gender through Women's Private Rituals in Traditional Finland. Helsinki: Finnish Literature Society. 
Stark-Arola, Laura 2002. The Dynamistic Body in Traditional Finnish-Karelian Thought. In: Anna-Leena Siikala (ed.) Myth and Mentality. Studies in Folklore and Popular Thought. Helsinki: Finnish Literature Society, pp. 67-103.

Stark, Eija 2011. Köyhyyden perintö. Tutkimus kulttuurisen tiedon sisällöistä ja jatkuvuuksista suomalaisessa elämäkerta- ja sananlaskuaineistoissa. [The Legacy of Poverty. A Study of the Substance and Continuity of Cultural Knowledge in Finnish Biographical and Proverbial Texts.] Helsinki: Suomalaisen Kirjallisuuden Seura.

Strauss, Claudia 1997 [2008, doi: 10.1525/can.1997.12.3.362]. Partly Fragmented, Partly Integrated: An Anthropological Examination of "Postmodern Fragmented Subjects". Cultural Anthropology, Vol. 12, No. 3, pp. 362-404.

Talve, Ilmar 1997. Finnish Folk Culture. Helsinki: Finnish Literature Society.

Thompson, Edward Palmer. 1991. Customs in Common. London: The Merlin Press.

Townsend, Peter 1979. Poverty in the United Kingdom. A Survey of Household Resources and Standards of Living. Harmondsworth: Penguin Books Ltd.

Urponen, Kyösti 1994. Huoltoyhteiskunnasta hyvinvointivaltioon. [From a Poor Relief Society to the Welfare State.] In: Jouko Jaakkola \& Panu Pulma \& Mirja Satka \& Kyösti Urponen (eds.) Armeliaisuus, yhteisöapu, sosiaaliturva. Suomalaisen sosiaalisen turvan historia. [Charity, Communal Help, Social Security. History of Finnish Social Security.] Helsinki: Sosiaaliturvan keskusliitto, pp. 163-260.

Wordie, J. Ross. 1989. Introduction. In: C. W. Chalkin \& J. R. Wordie (eds.) Town and Countryside. The English Landowner in the National Economy, 1660-1860. London \& Boston: Unwin Hyman, pp. 1-25. 